InOedia $\quad \begin{aligned} & \text { InMedia } \\ & \text { The French Journal of Media Studies }\end{aligned}$

5 | 2014

Media and Diversity

\title{
“It's Not Necessary but It's Nice"? Reflections on the Role of Media Produced by and for Lifestyle Migrants
}

Inês David

\section{(2) OpenEdition \\ Journals}

Electronic version

URL: http://journals.openedition.org/inmedia/785

DOI: 10.4000/inmedia.785

ISSN: 2259-4728

Publisher

Center for Research on the English-Speaking World (CREW)

\section{Electronic reference}

Inês David, " "It's Not Necessary but It's Nice"? Reflections on the Role of Media Produced by and for Lifestyle Migrants », InMedia [Online], 5 | 2014, Online since 17 October 2014, connection on 08

September 2020. URL : http://journals.openedition.org/inmedia/785 ; DOI : https://doi.org/10.4000/ inmedia.785

This text was automatically generated on 8 September 2020

(c) InMedia 


\title{
"It's Not Necessary but It's Nice"? Reflections on the Role of Media Produced by and for Lifestyle Migrants
}

\author{
Inês David
}

I would like to thank the anonymous reviewers for the helpful comments as well as to Marta Rosales and Sónia Ramalho for insightful inputs to earlier versions of this paper.

1 "It's not necessary, but it's nice" was the title and chorus of a song from "Churchill, the Musical" - a play written and performed in 2010, in the Algarve, by the British residents that this article focuses on. Volunteering to help backstage was a strategy to study radio produced by and for minorities in Portugal: the play was widely present in the broadcasts of Bright FM Algarve, the station elected as a case study. ${ }^{1}$ Pre-recorded promotional clips, interviews with actors, directors and writers, as well as the live coverage of the premiere, engaged radio advertisers, guests and listeners. Participating in the play thereby facilitated the exploration of different relationships comprising the social life of the radio. Whilst watching the protagonist's performance from backstage, it struck me that the expression "it's not necessary, but it's nice" described more than Churchill's extravagant tastes. It seemed to qualify some of the practices through which the self-designated "expatriates" related to their adopted home - not least through the station.

Indeed, Bright FM Algarve does not seem to be a necessary element in the daily lives of these foreign residents. Founded in 1992, it is but one of the various locally produced English-speaking media. It adds not only to the four local newspapers, the array of leisure-themed magazines and the ubiquitous small media (i.e. pamphlets, free maps, business cards), but also to the various online forums, directories and blogs focused on life in the Algarve. Practical information for settling in and navigating the context of residence can easily be found in the latter - more so than on the radio, since the translation of local news into English had to be discontinued around 2009 due to 
financial restraints. Moreover, the satellite television and radio channels that are everpresent in British houses, bars and restaurants across the Algarve, along with Internetbased communication tools (e.g. Facebook or Skype), largely fulfill various communicative needs (connectivity, entertainment, etc.). Provided such a public sphericule $^{2}$, what is the need, place and function for a local radio station?

The research presented in this paper was designed to investigate the role of radio made by and for migrants in the management of their cultural identity during processes of reterritorialization. It aims at understanding how radio assists in thinking, experiencing and making sense of transnational mobility and international relocation. The choice of a local station largely catering to a self-designated "expatriate" population resulted from an initial mapping of the existing radio initiatives in Portugal. As discussed below, the case provided productive avenues to discuss key themes informing the research design (namely, dynamics of visibility in the public space, inclusion/exclusion, cultural reproduction and transnational connectivity). To be sure, although Bright FM addresses all Portuguese and English-speaking locals, tourists and migrants, the research focused on the group most strongly involved in the production and consumption of the radio. The British have also been the longest-standing and most prominent foreign presence in the region. ${ }^{3}$ Despite not qualifying themselves as migrants, the "expatriates" do re-locate in the Algarve with the intention of creating a new (often permanent) home.

This paper argues that the case of a local radio station catering to lifestyle migrants "relatively affluent individuals moving ... to places which, for various reasons, signify for the migrants something loosely defined as quality of life" ${ }^{4}$ inscribes a counterpoint in the minority media literature besides signaling an under-researched area. It further proposes that the specificities of the case pertain to radio's unique contributions to the process of establishing a connection to place for relatively privileged populations settling in touristic settings. It starts by discussing the broader mapping of the minority radioscape in Portugal that informed the choice of the case study. It then explores the pertinence of considering relatively privileged minority populations. Whilst situating Bright FM in relation to the main themes and issues of minority media studies, it describes the "expatriates" animating it and its way of creating a connection to place. It finally closes with suggestions on exploring the mediations of such populations further.

\section{Minority Radio Mapping}

5 In order to choose a case study for research, I conducted a mapping of the existing minority radio initiatives. These are concentrated in the local radio sector and benefit from no formal structure connecting, let alone organizing, them. As such, building on previous assessments of the minority mediascape, ${ }^{5}$ the mapping exercise consisted of a telephone survey amongst the 347 local radio stations listed on the telecommunications regulating authority's (ANACOM) website. ${ }^{6}$ Although it did not include online (and unlisted) stations, it considered also stations with national coverage for the sake of contextualizing minority radio initiatives.

6 From June 2009 through June 2010, I asked 140 radio directors, program producers, and fellow radio practitioners about the existence of shows made by and/or for foreigners in their station. ${ }^{7}$ The 26 positive responses were explored through a short interview 
schedule concerning the initiative's establishment history (motivations of those involved; human, technical and financial resources gathered; goals and target audience of the initiative; similar past initiatives and reason for their termination) and production dynamics (e.g. relationship with the station, synergies with listeners). Following the methodology for the shows on nationwide stations, I also listened to the programs and noted their schedules, playlist structures, hosts' mode of address, location covered in the news when these were provided, spaces for and modes of participation of listeners, discourses addressing communities, genre of music, services and products advertised, and references to other media). ${ }^{8}$ In the cases of nine potential case studies, I visited the studios as well as other relevant locations (community centers, restaurants, clubs) and further explored the aforementioned topics with presenters, station directors and, sometimes, listeners who were suggested by the shows' hosts.

7 Notably, provided the volatile nature of a sector that is highly dependent on human and technical resources, the mapping sketches only a portrait of the national radioscape's configuration at the time of research. Moreover, the assessment was meant to be informative rather than exhaustive. The three previously established selection criteria consisted of the following: being established for more than one year (so as to avoid short-lived initiatives and secure an object of study for the duration of the project); actively engaging the audience (so as to complementarily explore production and consumption dynamics); and reflecting the experiences of mobility and settlement of a migrant population (provided the goal was to research international mobility and relocation processes more than second-generation dynamics).

\section{General Features of the Minority Radio Landscape}

8 The most salient contours of the minority radioscape opposed shows focused on cultural diversity from other spaces that were more oriented to community-making processes. The first group of stations (5) ${ }^{9}$ included a) programs usually aired on stations with national coverage that were focused on sensitizing for interculturality, and b) spaces promoted by local organizations and activists who explored the complex nature of diversity and intercultural dialogue. These shows described situations of successful adaptation and establishment in a new country, and discussed issues concerning migrants in Portugal whilst, more or less explicitly, advocating for their rights. Together, these programs project a positive image of Portugal as a currently culturally diverse country; they explore people's life stories as they settle into their new home, give visibility to the work of associations facilitating that process, and register firsthand accounts of an increasingly open and welcoming society. Additionally, they emphasize the added value of diversity when not only promoting and praising the presentation of multiple perspectives on various subjects, but also when problematizing the realities of diversity (through the unpacking of stereotypes).

9 To be sure, programs invite foreigners (academics, public figures and directors of nongovernmental organizations) to talk-shows so as to comment on national current affairs, contextualize, clarify and discuss news (e.g. about the changes in European regulations hampering entrance and circulation), and share experiences and ideas about what to expect - and what to comply with - when moving to Portugal. In the more activist-oriented shows, concrete discussions about the slanted structures of 
opportunities can be paired with calls for public demonstration against policies leaving migrants vulnerable. Instances triggering this pairing include obstructed access to the job market or the process of renting a house because of accents and skin color. Ultimately, their combined work resonates with the definition of "diversity media", i.e. forums that, by

giving a voice to the diversity of the components of contemporary European societies ... make the general public aware of the main economic, social, cultural and political issues and dynamics arising from the diversity of today's European societies. $^{10}$

10 In turn, the second and biggest group (29), was more focused on catering to the particular populations they were produced by and for, although sometimes with the assistance of Portuguese radio practitioners. These include, in addition to the three stations (founded by Brazilian and British migrants) and three shows on the public service channel RDP África, ${ }^{11}$ spaces ranging from 15 minutes to 8 hours made by and/ or specifically targeting the following groups: people from Portuguese-speaking African countries, such as Cape Verde, Guinea, Angola and Mozambique (8); Eastern Europeans, mostly from Ukraine, Romania, Moldavia and Russia (5); Western and Northern Europeans, mostly from the United Kingdom, Germany, France and the Netherlands (3); Asians from India and China (3); and Latin Americans, namely from Brazil and Venezuela (4). Though the first program started in 1987, most have emerged since the 1990s, coinciding with the transformation of Portugal from an emigration country to an immigration destination. Massive arrivals of Brazilians (in the 1980s and early 2000s) and Eastern Europeans, namely Ukrainians and Romanians (in the early 2000s), added to ongoing flows from the former African colonies that had started in the mid 1970s. ${ }^{12}$ Most evidently, shows by and for Eastern European populations accompanied the arrival and departure of large numbers of people from those countries. ${ }^{13}$

11 These shows are particularistic, to use Dayan's (1998) expression, ${ }^{14}$ to the extent that they promote a sense of belonging based on a series of references that construct and sustain imagined communities..$^{15}$ To be sure, not all groups are based on nationality, as programs are also catered to populations according to regional markers, such as "Eastern Europeans" or "Africans". These programs draw on specific languages and a number of cultural features comprising common denominators amongst people who may otherwise remain strangers to each other - namely if they are not involved in migrant associations, clubs or religious structures. Regardless, references speak to listeners whilst possibly not being even intelligible to a wider audience, as is the case with the devotional musical references at the beginning of a show that strives to bring together the different religious communities amongst the Indian population in Lisbon. In any case, programs vary in their mode of projecting their "we"-ness (which can be more essentialized or plural, or more or less close-knit) and of sustaining it (e.g. welcoming interaction on air, whether live or asynchronously, promoting off-air sociabilities, focusing primarily on the celebration of musical repertoires, and providing news).

12 Moreover, there is a concern to make broadcasts accessible to a wider audience whilst providing a service for peers. Most shows' modes of address and frequent use of the Portuguese language presuppose the average national listener. Nevertheless, broadcasts focus on catering to a specific audience's interests, needs, and tastes by providing, for instance, newscasts covering particular locations, useful information for settling into the country (e.g. procedures to have one's qualifications recognized), and 
musical genres otherwise not aired in Portugal. Presenting their culture was motivated by a desire to add themselves (producers and consumers) to the mediascape.

Porque nós não queremos excluir-nos. É incluir. E todo o cabo-verdiano fala português. Quem quiser falar em crioulo pode falar, mas emitimos em Português. E não traduzimos quem fala em crioulo.

[Because we don't want to segregate ourselves. It's to include. And every Cape Verdean speaks Portuguese. Anyone wishing to speak in Creole can do so, but we broadcast in Portuguese. And we don't translate who speaks in Creole [author's translation] (Interview excerpt, producer of a Cape Verdean show)

However, this self-presentation was not a reflexive account of their position in the mediascape or Portuguese society. In other words, despite displaying "a genuine willingness to open up to the social ... environment in which they operate", ${ }^{16}$ the shows merely inform about diversity and inscribe it in the mediascape. For instance, they give visibility to the festivities celebrating national days, initiatives of local organizations, concerts by artists from the countries of origin or inter-religious meetings. In that sense, on the one hand, they create a "third space of enunciation ${ }^{17}$ from which they negotiate cultural backgrounds and new experiences in Portugal. ${ }^{18}$ To be sure, the programs foster the creation and maintenance of subjectivities mixing cultural heritages and affiliations to other places with identifications with the current country of residence. Frames of reference become intertwined on air in a quotidian mix of, for example, updates on the Portuguese football team's performance in international championships followed by top-10 features with the latest music hits from Bollywood, or greetings from friends and family abroad celebrating "Mother's Days" on both the Portuguese and Venezuelan (or other) dates. Shows are thus sites for the expression of situated modalities of belonging to transnational social fields. On the other hand, these programs showcase diversity without advocating for it or problematizing its realities like the aforementioned shows. In that sense, they do not reach out for interculturality.

Moreover, this form of self-inscription in the mediascape did not evidence a strategy to gain visibility in the public space so as to countervail exclusion - which is often discussed in the literature as a central function of minority media. ${ }^{19}$ Although effectively adding presences to the mediascape, what this exploratory research suggests is that radio shows are not driven by or focused on symbolic or social exclusion, even when marginalization is known to constrain people's opportunities and everyday encounters (e.g. the case of Cape Verdeans and Sao Tomeans). ${ }^{20}$ The only instance suggestively alluding to problems of exclusion was the "legal office" feature of African-oriented shows, where a lawyer responds to enquiries posed by listeners about legal matters (e.g. exploitation at work, family reunification, legalization processes). These pre-recorded questions and answers occupy a short time slot and are not further evoked or discussed in the program.

\section{A Different Perspective}

15 This scenario informed the selection of the case study, given the ways it could be related to the literature. Whilst concerns and efforts to overcome the difficulties alluded to above may be articulated elsewhere, ${ }^{21}$ what this panorama suggests is that, generally, broadcasts are not used to discuss experiences of inclusion and exclusion in association with debates about coping with a fraught social position derived from the migrant condition. In that sense, they do not necessarily operate as a political 
instrument to voice the problems of migrant constituencies and to facilitate empowerment and social change through calls for public recognition. Representation in the media does not necessarily entail representation through the media, although it fulfills various other functions (e.g. expressing identity and fostering participation in communities within and across borders). Yet, the implicit conflation of dimensions of representation (depicting the minority at stake and speaking in its name, as discussed by Spivak (1988)) is common in conceptualizations of minority media through the "ethnicization thesis", to use Kosnick's expression. ${ }^{22}$ This "thesis" holds that minorities' access to the media enables authentic representations of "themselves" and, therefore, legitimates the voicing of their interests and concerns in a double sense of portraying and standing for the migrants. ${ }^{23}$ As the author notes, it overlooks the fact that any population is riddled with tensions that polarize diverse social and material statuses and perspectives. Furthermore, it reduces the complex issue of migrant-mediated selfrepresentation to a matter of access to resources and to the opposition of cultural minorities and national majority.

16 To complement Kosnick's argument, which discusses the cases of subordinated minorities ${ }^{24}$ it should be noted that the ethnicization thesis also unhelpfully presumes that the migrant condition is disadvantaged and marginalized. Framing minority media through the lens of discussions based on exclusion, whilst pertinent, can incur the danger of besetting, from the start, their social location as "minority-bound". Indeed, holding alterity and a pre-set power relation as a point of departure pertains not only to their strength in the mediascape (in terms of numbers and visibility) but also, and mostly, to the connotations associated with the migrant designation and condition.

The word immigrant, especially, is "a catch-all category, combining ethnic and class criteria, into which foreigners are dumped indiscriminately, though not all foreigners and not only foreigners" (Balibar 1991: 221). The immigrant becomes a chief characteristic that replaces race in a racist typology; it is a form of "racism without races", a verbal construction of opposition between Europe and the Other. ${ }^{25}$

17 The inference that is extended to migrants' media indicates that certain populations of, namely, higher classes and/or European origin, are not perceived (nor perceive themselves) as ethnic or as migrants - despite being foreigners residing in a migratory context all the same. Ayse Çaglar, in a call for a focus on what lies beyond ethnic difference and visibility, notes the danger of remaining too close to the categories of practice that present themselves as evident:

My point is that this evident visibility comes to dominate our own theoretical horizons as anthropologists and sociologists almost as much as it does those of the racists, ethnic brokers or politicians who seek to control, resist and domesticate the spatializing process itself. To "write against culture" in this context, in which space is a powerful metaphor for sociality, is to locate other, more invisible, processes that go towards the creation of culture and identity. ${ }^{26}$

18 In other words, the systematic assumption that minorities are somehow marginalized leads to disregarding relatively privileged minorities (and segments of minorities) that remain under-conceptualized, as ElHajji (2012) notes. ${ }^{27}$ The British, whom this article focuses on, are indeed still largely under-studied, ${ }^{28}$ namely in Portugal..$^{29}$

19 The choice of the atypical case of a station founded by and largely catering to British self-designated "expatriates" not only fit the criteria established at the outset, but also posed the possibility to discuss a perspective of power dynamics that has so far been overlooked in studies analyzing the relations between media and migration. 
Specifically, it promised to raise questions concerning the role of mediated selfrepresentation in a migratory context from the point of view of relative privilege. Indeed, despite differing amongst themselves in terms of financial comfort and stability, the British residents in the Algarve chose where, how and for how long to move in order to experience a "better quality of life" - a subjective reason that rests on choice more than on (economic-based) need to move. They are better conceptualized as lifestyle migrants ${ }^{30}$ provided that their move is enabled by sufficient resources to pursue amenities such as "warm climate", "beautiful scenery", "relaxed pace of life" and "a comparatively lower cost of living".

Exploring this perspective inscribes other types of populations in minority media studies by analyzing them according to the same lenses and theoretical tools. It can help to avoid differentiating people engaged in international relocation on the basis of preconceptions about social standing. Moreover, it enables contextualizing and nuancing the representations associated with such "expatriate" populations by grounding them in concrete lived experiences that unravel otherwise invisible processes of cultural identity reconstruction - as other researchers investigating how minority media facilitate these processes have argued for the case of subaltern populations. ${ }^{31}$

21 An ethnographic approach was taken to research Bright FM Algarve. Fieldwork comprised short and long visits to the Algarve between July 2010 and May 2012. To "follow the radio", to use Marcus's (1995) expression, ${ }^{32}$ I traced radio-informed relations from the broadcasts and the studios to various contexts: meetings with clients wanting to advertise their businesses; live coverage of events (e.g. inauguration and anniversary of lifestyle migrants' commercial establishments); functions organized by and/or promoted through the station (such as theater plays and quiz nights); and shops, homes and, occasionally, car-rides from which regular listeners tune in. To identify the station's role for people producing and consuming it, I considered the radio both as a product (in terms of content that is circulated and appropriated) and a social practice (of both production and consumption). ${ }^{33}$ In addition to observation at the station, I interviewed Bright FM Algarve's team members, listeners and announcers, in addition to other media practitioners, British local authorities and numerous other people who did not follow the radio but were involved in relevant social fields. ${ }^{34}$

\section{British Lifestyle Migrants in the Media}

The representation of the British in the mainstream media differs from that of other minorities. As noted in a recent report on the depictions of migrants in European national media, the British are exempted from such a label and its connotations. ${ }^{35}$ In the Algarve, where they constitute approximately $10 \%$ of the region's population with an estimated 40,000 full-time residents, ${ }^{36}$ they blend in with tourists more than with other migrants living in the region (the majority of whom are Brazilians, who outnumber the British, and Ukrainians and Romanians). ${ }^{37}$ As Torkington notes, ${ }^{38}$ like other resident Northern Europeans (German, Dutch or Swedish), they socialize, dress, speak and spend time in the same places as tourists - namely, eating, drinking and enjoying sports at places like restaurants, golf courts, pubs and marinas. Accordingly, they are not portrayed in the mainstream media of host contexts based on cold, 
generalizing, sensational and dehumanizing images that strip them of agency and reduce them to a "problem" requiring active solutions on the part of authorities:

The active role of work-seeking, non-European immigrants in the integration process, their individual and collective agency in the creation of positive outcomes, their point of view as protagonists of integration but also of full lives with economic, social and personal goals - all aspects easily and naturally elaborated in stories of moneyed European entrepreneurial or professional expatriates - are often obscured in media treatment of poor arrivals. "Immigrants", as a vague social category, are instead most often portrayed as passive embodiments of a "problem". 39

Brazilians, Africans from Portuguese-speaking countries, and Eastern Europeans - who, combined, are the most numerous and visible foreigners in Portugal ${ }^{40}$ - have been indeed associated in mainstream media with crime, illegality and sensationalist narratives based on security concerns. ${ }^{41}$ This despite the fact that Portuguese media have been increasingly preoccupied with the framing, sources, themes and points of view of stories. ${ }^{42}$ Notably, relatively affluent populations can too, objectively, constitute a "social problem": their presence has been known to hinder the livelihoods of residents (e.g. through the inflation of property prices to a point where they become unaffordable to locals) as well as in terms of natural landscapes and local economies in the new context of residence, thereby creating tensions with local populations. ${ }^{43}$

Yet, apart from the intense media coverage of the disappearance of Madeleine McCann and of the attempts to find her, ${ }^{44}$ the British have not been commonly reported on in Portuguese media. Along with other Northern Europeans, they only recently figured more visibly in news about tourism dynamics and, specifically, a campaign to attract affluent retirees. The governmental plan to transform the Algarve into "Europe's Florida" 45 through the "Retirement in the Sun Program" has motivated news pieces, features and debate programs on television, radio and in newspapers. Amidst reports on the potentialities, feasibility and implications of the program, which is meant to create favorable conditions for the settlement of European retirees in the region, ${ }^{46}$ the British have been portrayed positively. Usually, as affluent individuals who may not be well versed in Portuguese but are a stable, fairly integrated community, besides constituting a strong market for tourism and second-home ownership (see, for example, LUSA (2013), ${ }^{47}$ Marujo (2012), ${ }^{48}$ Oliveira (2012) ${ }^{49}$ or Serafim (2011). ${ }^{50}$

In an interesting further contrast with other minorities, negative portrayals come mostly from the mainstream media from the country of origin. British mainstream media have notoriously portrayed these foreign residents as people solely interested in "recreating England in the sun", spending their time in "ghettos" and disregarding, at times even disdaining, the people and culture of their new home..$^{51}$ The lifestyle migrants have also been noted to insulate themselves from local society, put little effort into learning the local language and to focus only on enjoying local amenities. ${ }^{52}$ Though I do not dispute these characterizations, in my fieldwork I did not often observe these representations being lived out in practice. Rather, the references to the stereotype revealed the diverse and textured ways in which people position themselves and others in relation to it. More importantly, I observed that English-language media had the potential to contribute to seclusion. Most people's media diets barely change when moving, given satellite and online technologies. With the availability of local English-language newspapers, reading the national tabloids found on café tables represents, for many, an 
opportunity to practice (their usually barely functional) Portuguese more than to follow national current affairs. Often not attentively following reporting on national issues in either, various people fail, for example, to name the country's leaders. This makes one wonder "whether integration is a relevant concept at all for British residents and seasonal migrants along the Mediterranean coasts of southern Europe". ${ }^{3}$ Remarkably, such self-segregation lies at the core of arguments (however unfounded they may be) criticizing minority media for inhibiting integration when fostering cultural reproduction..$^{54}$

\section{Bright FM Algarve as Minority Media}

\section{A Minority Radio Station?}

Considering Bright FM Algarve as a minority radio station offsets much of the literature informing the research design. One of the main points raising the question of whether this station can be classed as minority radio concerns the invisibility that also qualifies the population it serves. Indeed, Bright FM does not create a distinctive cultural sonority and presence like other minority initiatives. First, it blends in with the approximately 20 stations in the region, to the point of being hardly distinguishable given its playlist. According to the station's director and programming coordinator, it aims to create an upbeat and positive tone so as to associate the touristic region of the Algarve with good feelings and memories. In part, accomplishing this includes playing the most recent anglophone rock-pop music hits, which, however, now color most of the radioscape in Portugal anyway. Even the "golden oldies" that two popular live shows of Bright FM play, so as to cater to a particular segment of the population (the retirees), can be heard on national networks that specialize on sonorities of the last three decades. Notably, such hegemonic references are sometimes actively avoided by minority stations such as Radio MultiKulti in Germany, which played world music in between shows by different migrant groups. ${ }^{55}$

Second, like the station, the residents are so inter-related with tourism that they fade into that industry's backdrop, which sets the rhythm of life in the region. To be sure, a significant specificity of lifestyle migration is that people move fluidly between categories connecting tourism and migration along a continuum..$^{56}$ Many residents started as tourists before deciding to settle in Portugal. Later, they then became only visitors or second-home owners after returning to the UK or moving to other destinations, such as Thailand. As mentioned earlier, they also share tastes, hobbies and outlook. The radio station, like the other media listed earlier, caters simultaneously to all - which complicates the notion of a minority audience with situated needs and interests. This mixture becomes clear when the authorities' summer messages cautioning holiday-makers against landslides along the beach follow a weekly interview with a financial adviser, aimed at full-time residents, focused on management of UK-based pensions and investments.

Only the advertisements and presenters using English denounce the station's identity when moving along the dial. However, what this signals is that the British and Bright's invisibility results from the singular juxtaposition of a symbolically powerful minority and a touristic context, where English is the lingua franca. In other words, one of Bright's particularities consists of broadcasting from a semi-periphery ${ }^{57}$ to a population 
whose references are dominant because they moved from a nearby global center. ${ }^{58} \mathrm{Can}$ media made by and for lifestyle migrants be considered minority media?

The answer lies, partly, in that very tourism-migration nexus. ${ }^{59}$ As mentioned, despite the fact they do not consider themselves migrants, the British do re-locate in the Algarve with the intention of creating a new home. Additionally, alongside their constant efforts to distinguish themselves from masses of tourists (for example, in comments that criticize the latter's lack of ability and/or interest to experience the "real" local culture), their position as non-holidaymakers results frequently from their very involvement in the tourism and migration industries. Although early retirement pensions and/or accumulated capital may foreground the plans of moving, many British become involved in businesses catering to the interests and needs of visitors, second-home owners and fellow residents. For some, what renders remaining in the Algarve and living a "better life" viable is, for instance, being an English-speaking and certified doctor or assisting with the process of finding, buying, renovating, securing and/or moving into a house in English, through a (typically) small company. As such, resembling other cases in the mapping, the radio assists in securing the income of the population by advertising services on air.

\section{A Minority Radio Station!}

Bright FM Algarve further relates to the themes in the literature, although in particular ways. In what concerns processes of settling and navigating the host country, ${ }^{60}$ for instance, live show hosts take it upon themselves to underline new laws affecting the residents. These, however, pertain to markers of material comfort rather than to economic difficulties: licenses for boreholes in properties (sometimes used as pools), changes in the tax regimes in Portugal and the UK (affecting investment plans in the stock market), or heightened tolls on the highway (adding to the already expensive matriculation of cars). Moreover, highlighting local events may also signal an inclusion into like-minded "expatriate" networks more than to local realities, as municipal markets and festivities are announced alongside quiz nights, golf tournaments, pantomimes or dog shows.

Furthermore, transnational connectivity is a key feature. Benefitting from the innovations in transport and communication, Bright FM became an active agent in placing the UK in the Algarve's neighborhood (in the sense that Appadurai (1996) uses the term to visualize the configuration and maintenance of localities). ${ }^{61}$ The proximity is materialized, in practice, by the frequent advertisements of companies based in the UK but with representations in Portugal (e.g. consulting and banking firms) or transporting goods back and forth (e.g. to provide products for supermarkets and wholesalers). Broadcasting programs produced in the UK, or the constant participation of listeners who tune in online from abroad, are also singular forms of materializing this connectivity. Consequently, audience members share and accompany the stories of those who have returned to the UK after the loss of their partner but come back frequently to visit friends, of second-home owners who are spending a few months in another country, or of regular visitors who connect with the sun and fun of their holiday place from cold and rainy homes. From abroad, some use the radio to stay present amongst their social networks through song requests and dedications, birthday and anniversary wishes, and notes about when they will be arriving. Such phatic 
messages would not find a place in letters to the editor in the local newspapers, which would be the next closest forum. radio aficionado who had been a radio pirate in the UK and Portugal. Bright FM constituted an opportunity to cater to a niche market that was not contemplated by local stations: it was uniquely positioned to provide the latest hits of the Anglo-Saxon music scene - no mean feat before the Internet was established - and to address English-speaking foreigners not only in their language, but also in familiar idiomatic expressions and accents. Since then it has been both feeding on and contributing to the tourism and second-home markets. Remarkably, although the commercial venture always employed a multinational team and boasted of serving "the multicultural communities of the Algarve" (namely by sustaining the only fully bilingual programming in the region), Bright was identified as "the English station" from the start.

Being a young Portuguese woman - thus constituting a member of the target audience elected to establish the station amongst the Portuguese - facilitated starting conversation with shop-owners who shared that perception and admitted to tuning in to the station mainly to attract tourists. Whilst cultural distance may have hampered access to some social dynamics within and around Bright FM, it also helped me notice the often disregarded cultural markers and practices emphasizing the connection to the UK. In a context of geographical proximity and highly mediated everyday lives, there are few objectifications of home and cultural identity like those apparent in other minority media ${ }^{65}$ In other words, more than traditional dates commemorating the UK's history (e.g. Guy Fawkes Night), which are signaled, the British cultural markers comprised more ordinary, but recurrent, references. These included humored comments comparing weather forecasts for the Algarve and the UK, bulletins updating the exchange rates daily, and a general discursive demarcation between an "us", the "Brits", that, significantly, often alternates with a wider sense of we-ness that is complicated by encompassing all "expatriates". These references all resonate with Bilig's (1995) description of "banal nationalism": symbolic references and practices that are often discarded in conversation as trivial, but can bear significant weight in practice. ${ }^{66}$ This is particularly illustrated by the following turmoil around the broadcast on Poppy Day: 
Len, the youngest host, filled in for a DJ who was on vacation this Remembrance Sunday morning. Although he had received instructions about the line-up of features, guests, and the particular way to honor Armistice Day, he knew he had the consent of the station director to "do his thing" provided he was "sitting in for the DJ, not replacing him". He therefore avoided allowing a two-minute silence on air following the last post (a bugle or trumpet call sounded by the British military), which is part of the ceremonial remembrance of those who lost their lives under military duty. In his mind, such a long silence is unthinkable on radio. He played the sound of bells and the last post, followed by a rather brief moment of silence. When I asked him about how the ritual is usually performed in the $U K$, he noted the rotation of images of soldiers on television during the silence. He hurried to mention that national radio would play soft music and the last post. But we were not in England. He argued it was unfit to bore people in Portugal with such an English thing and "dead time" on air. The English program producers and show hosts that I talked to on following shows, on the very same studio, could not agree less. In between songs, with no prompting, they commented that a longer silence should have been observed and that the "right" order for the ritual would be the sound of muffled bells, a two-minute silence and then the last post. ${ }^{67}$ taken for granted. Moreover, the author notes the importance of modes of address developing historically to adjust to the characteristics of the audience. Considering the particularities of the lifestyle migrant audience (e.g. the ambivalent stance of connection to place, claiming belonging but cultivating some social distance, as Benson and O'Reilly note ${ }^{71}$ ), radio is then particularly able to naturalize such a subject-position through a mode of address based on repetition, ephemerality and, given the local character of broadcasts, the sense of familiarity imprinted by geographical proximity. In other words, radio seems to contribute to naturalizing the "expatriates" stance of connection to the Algarve and its people, provided the singular affordances of aural and local communication.

\section{Conclusive Notes: "Expatriate" Media?}

Although the case of Bright FM Algarve does not linearly fit the category of minority media as discussed in that field's literature, it relates to it by providing a counterpoint to most cases analyzed. Like other initiatives identified in an exploratory mapping, it may not channel the voicing of the population's concerns and needs, but performs community-making and integration functions. Moreover, it also calls for transnational and identity-focused analyses for it contributes to connecting listeners to places of reference in the contexts of origin, residence and elsewhere, whilst addressing their tastes and interests. However, unlike other programs, Bright FM can easily go by unnoticed on the dial. Moreover, its audience remains largely invisible on national media and academic studies. The station's specificity lies in contributing to naturalizing the presence of these "expatriates" in the Algarve and, more importantly, 
their ambivalent stance of connection to their elected home. Given the radio's local and aural features, Bright plays into the mundane dimensions of everyday life, thereby normalizing the construction of a particular way of life in the destination context, and contributing to its reification. This role may not be necessary to enable settlement, "but it is nice", as the song mentioned in the beginning of the article suggested, for it facilitates the process.

Considering the array of novels written by lifestyle migrants about life in Portugal (and elsewhere) or the countless online forums operating as service and information directories (amongst other media, such as second-home acquisition shows on British television), it seems pertinent to further consider the mediations of, namely, lifestyle migrants. Exploring the specificities of locally produced media may not only be revealing of such specific flows, but also contribute to productively expanding the field by considering relatively privileged populations. Do locally produced media play into the (often media-informed) decision to move, after visiting? How are representations of peers, locals, "home(s)" and other places of reference complicated by them? What do these reveal about power dynamics in migratory contexts, and about the media's role in them? Can the discussion encompass other "expatriate" flows? These and other related questions warrants further investigation.

\section{BIBLIOGRAPHY}

ACIDI. List of migrants' and minorities' media. Lisbon: unpublished (provided upon the researcher's request), 2008.

Anderson, Benedict. Imagined Communities: Reflections on the Origin and Spread of Nationalism. London: Verso, 1983; rev. repr. 1991.

Appadurai, Arjun. Modernity at Large: Cultural Dimensions of Globalization. Minneapolis: University of Minneapolis Press, 1996.

Baganha, Maria Ioannis. “Imigrantes em Portugal: uma Síntese Histórica.” Ler História 56 (2009): $115-126$.

Bailey, Olga Guedes, Myria Georgiou, and Ramaswami Harindranath. "Introduction: Exploration of Diaspora in the Context of Media Culture." In Transnational Lives and the Media: Re-imagining Diaspora, edited by Olga Guedes Bailey, Myria Georgiou and Ramaswami Harindranath, 1-10. Basingstoke: Palgrave Macmillan, 2007.

Bastos, José, Maria João Rego, Rui Lopes, André Sendin, António Belo, and Carlos Andrade. Caracterização do Sector da Radiodifusão Local. Lisbon: Entidade Reguladora para a Comunicação Social, 2009.

Benson, Michaela, and Karen O’Reilly. “Lifestyle Migration: Escaping to the Good Life?” In Lifestyle Migration: Expectations, Aspirations and Experiences, edited by Michaela Benson and Karen O'Reilly, 1-13. Surrey and Burlington: Ashgate, 2009. 
Bhabha, Homi. "The Postcolonial and the Postmodern: The Question of Agency." In The Cultural Studies Reader, edited by Simon During, 189-208. London: Routledge, 1999.

Bilig, Michael. Banal Nationalism. London/Thousand Oaks/New Delhi: Sage Publications, 1995.

Blion, Reynald. “Europe's Ethnic Media and Diversity Media: Beyond Mere Visibility." In Media on the Move. Migrants and Minorities and the Media. 4th Symposium Forum Medien und Entwicklung (FoME), edited by Christoph Dietz and Petra Stammen, 65-69. Aachen: Catholic Media Council (CAMECO), 2009.

Brites, Rui, José Rebelo, and Isabel Ferin Cunha. “Imigrantes.” In Estudo de Recepção dos Meios de Comunicação Social Portugueses, 231-284. Lisbon: Entidade Reguladora para a Comunicação Social, 2009.

Carvalheiro, José Ricardo. "Da Representação Mediática à Recepção Política. Discursos de uma Minoria.” Sociologia, Problemas e Práticas 51 (2006): 73-93.

Chambers, Ian. "Travelling Sounds: Whose center, Whose Periphery?" In Otherness and the Media: The ethnography of the Imagined and the Imaged, edited by Hamid Naficy and Teshome Gabriel, 205210. Chur: Harwood Academic Publishers, 1993.

David, Inês, and Marta Rosales. “'Do It for Charity!' Radio's Mediation of Civic Engagement among British Ex-pats in Portugal.” Ethnography 15(1) (2014): 106-124.

Dayan, Daniel. "Particularistic Media and diasporic communications." In Media, Ritual and Identity, edited by Tamar Liebes and James Curran, 103-113. New York: Routledge, 1998.

Echchaibi, Nabil. “(Be)longing Media: Minority Radio between Cultural Retention and Renewal.” The Public 1 (2002): 37-50.

ElHajji, Mohammed. "Rio de Janeiro - Montreal: Conexões Internacionais/Ruídos Interculturais." In Diásporas, migrações, tecnologias da comunicação e identidades transnacionais = Diásporas, migraciones, tecnologías de la comunicación e identidades transnacionales = Diaspora, migration, communication technologies and transnational identities, edited by Denise Cogo, Mohammed ElHaji and Amparo Huertas, 31-42. Bellaterra/Barcelona: Institut de la Comunicació, Universitat Autònoma de Barcelona, 2012.

European Broadcasting Union (EBU) - Strategic Information Service. Migration: An Overview (vol. 45). Geneva: European Broadcasting Union, 2011.

Ferin, Isabel, Clara Almeida Santos, and Willy Filho. Media, Imigração e Minorias Étnicas 2005-2006. Lisbon: ACIDI - Observatório da Imigração, 2008.

Figueiredo, Alexandra. "Mapping Minorities and their Media: The National Context - Portugal." London, London School of Economics and Political Science, Dept. of Media, Program EMTEL II Research - Diasporic Minorities and their Media in the EU: a Mapping, 2003, accessed March 15, 2014, http://www.lse.ac.uk/media@lse/research/EMTEL/minorities/papers/portugalreport.pdf. Georgiou, Myria. Mapping Diasporic Media across the EU: Addressing Cultural Exclusion. Political Science. London: EMTEL II, Media@LSE, London School of Economics and Political Science, 2003.

-. "Diasporic Media Across Europe: Multicultural Societies and the Universalism-Particularism Continuum." Journal of Ethnic and Migration Studies 31(3) (2005): 481-498.

-. "Transnational Crossroads for Media and Diaspora: Three Challenges for Research." In Transnational Lives and The Media: Re-imagining Diaspora, edited by Olga Guedes Bailey, M. Georgiou, and R. Harindranath, 11-33. Basingstoke: Palgrave Macmillan, 2007. 
Gitlin, Todd. "Public Sphere or Public Sphericules?" In Media, Ritual and Identity, edited by Tamar Liebes and James Curran, 169-173. London: Routledge, 1998.

Huete Nieves, Raquel, Alejandro Mantecón Terán, and Tomás Mazón Martinez. “Analysing the Social Perception of Residential Tourism Development." In Proceedings of the IASK International Conference: Advances in Tourism Research, edited by Carlos Costa and Pedro Cravo, 153-161. Aveiro: IASK, 2008.

Instituto Nacional de Estatística (INE), I. P. Censos 2011 Resultados Definitivos - Algarve. Lisbon: INE, 2012.

Karim, Karim H. "From Ethnic Media to Global Media: Transnational Communication Networks Among Diasporic Communities." ESRC Transnational Communities Research Program, Working Paper Series, WPTC-99-02, 1999, accessed May 6, 2014, http://www.transcomm.ox.ac.uk/ working\%20papers/karim.pdf.

Sunset Lives: British Retirement to the Mediterranean. Oxford: Berg, 2000.

Kosnick, Kira. "Ethnic Media, Transnational Politics: Turkish Migrant Media in Germany." In Transnational Lives and The Media: Re-imagining Diaspora, edited by Olga Guedes Bailey, M. Georgiou, and R. Harindranath, 149-174. Basingstoke: Palgrave Macmillan, 2007.

Larkin, Brian. "Indian Films and Nigerian Lovers: Media and the Creation of Parallel Modernities." Africa 67(3) (1997): 406-439.

Marcus, George. "Ethnography in/of the World System." Annual Review of Anthropology 24 (1995): 95-117.

Matsaganis, Matthew, Vikki Katz, and Sandra Ball-Rokeach. Understanding Ethnic Media: Producers, Consumers and Societies. Thousand Oaks: Sage, 2011.

O'Reilly, Karen. “'Blackpool in the Sun': Images of the British on the Costa del Sol." In Media and Migration: Constructions of Mobility and Difference, edited by R. King and N. Wood, 173-188. London and New York: Routledge, 2001.

Riggins, Stephen Harold. “The Media Imperative: Ethnic Minority Survival in the Age of Communication." In Ethnic Minority Media. An International Perspective, edited by Stephen Riggins, 1-20. Los Angeles: Sage, 1992.

Rigoni, Isabelle and Eugénie Saitta. "Democratizing the Public Space? Ethnic Minority Media in a Glocal Context." In Mediating Diversity in a Globalised Public Space, edited by Isabelle Rigoni and Eugénie Saitta, 1-21. Basingstoke: Palgrave MacMillan, 2012.

Salim, Isabel Câmara. Os meios de comunicação étnicos em portugal. Lisbon: ACIDI - Observatório da Imigarção, 2008.

Scannell, Paddy. "For-Anyone-as-Someone Structures." Media, Culture and Society 22 (2000): 5-24.

Silvano, Filomena, Marta Rosales, and Sónia Ferreira. "Gente da Nossa: Uma construção mediática da ideia de 'comunidade Portuguesa'." Portuguese Studies Review 20(2) (2012): 143-169.

Silverstone, Roger, and Myria Georgiou. "Editorial Introduction: Media and Minorities in Multicultural Europe." Journal of Ethnic and Migration Studies 31(3) (2005): 433-441.

Sousa Santos, Boaventura. "Estado e sociedade na semiperiferia do sistema mundial: o caso português." Análise Social XXI (87-89) (1985): 869-901.

Spitulnik, Debra. “Anthropology and Mass Media.” Annual Review of Anthropology 22(1) (1993): 293-315. 
Spivak, Gaiatri. “Can the Subaltern Speak?" In Marxism and the Interpretation of Culture, edited by Cary Nelson and Lawrence Grossberg, 271-313. Urbana: University of Illinois Press, 1988.

Sriskandarajah, Dhananjayan, and Catherine Drew. Brits Abroad: Mapping the Scale and Nature of British Emigration. London: Institute for Public Policy Research, 2006.

Torkington, Kate “Defining Lifestyle Migration.” Dos Algarves 19 (2010): 99-111.

Trovão, Susana, and Sónia Ramalho. Repertórios Femininos em Construção num Contexto Migratório Pós-Colonial: Dinâmicas Familiares, de Género e Geração, vol 1. Lisbon: ACIDI, 2012.

Vertovec, Steven. "Fostering Cosmopolitanisms: A Conceptual Survey and a Media Experiment in Berlin." ESRC Transnational Communities Research Program, Working Paper Series, WPTC-2K-06, 2000, accessed May 6, 2014, http://www.transcomm.ox.ac.uk/working\%20papers/vertovec.pdf.

Williams, Allan M. and C. Michael Hall. "Tourism, Migration, Circulation and Mobility: The Contingencies of Time and Place." In Tourism and Migration: New Relationships between Production and Consumption, edited by C. Michael Hall and Allan M. Williams, 1-53. Dordrecht: SpringerScience+Business Media, B.V, 2002.

\section{ENDNOTES}

1. For the sake of privacy, people and institutions have been renamed.

2. Todd Gitlin, "Public Sphere or Public Sphericules?," in Media, Ritual and Identity, ed. Tamar Liebes and James Curran (London: Routledge, 1998), 169-173.

3. Russel King, Anthony Barnes and Allan Williams, Sunset Lives: British Retirement to the Mediterranean (Oxford: Berg, 2000).

4. Michaela Benson, and Karen O’Reilly, “Lifestyle Migration: Escaping to the Good Life?" in Lifestyle Migration: Expectations, Aspirations and Experiences, ed. Michaela Benson and Karen O'Reilly (Surrey and Burlington: Ashgate, 2009), 621.

5. ACIDI, List of migrants' and minorities' media. Lisbon: unpublished (provided upon the researcher's request), 2008; José Bastos, Maria João Rego, Rui Lopes, André Sendin, António Belo, and Carlos Andrade, Caracterização do Sector da Radiodifusão Local (Lisbon: Entidade Reguladora para a Comunicação Social, 2009); Alexandra Figueiredo, "Mapping Minorities and their Media: The National Context - Portugal," London, London School of Economics and Political Science, Dept. of Media, Program EMTEL II Research - Diasporic Minorities and their Media in the EU: a Mapping, 2003, accessed March 15, 2014, http://www.lse.ac.uk/media@lse/research/EMTEL/minorities/papers/ portugalreport.pdf; Isabel Câmara Salim, Os meios de comunicação étnicos em portugal (Lisbon: ACIDI - Observatório da Imigarção, 2008).

6. The directory is available online, at http://www.anacom.pt/render.jsp? categoryId $=42701$, accessed January 15, 2014. For this project, I considered only stations that operate in FM and, provided the limited financial resources and time, in continental Portugal.

7. Failure to contact the remaining operators derived from incorrect contact information in the latest version of the database (e.g. outdated phone numbers) and inability to reach directors, coordinators or practitioners able to provide information. 8. This task was impossible in the case of shows addressing Eastern Europeans solely in their languages. 
9. Numbers in parentheses designate the number of stations included in the indicated group.

10. Reynald Blion, “Europe's Ethnic Media and Diversity Media: Beyond Mere Visibility," in Media on the Move. Migrants and Minorities and the Media. 4th Symposium Forum Medien und Entwicklung (ME), ed. Christoph Dietz and Petra Stammen (Aachen: Catholic Media Council (CAMECO), 2009), 68-69.

11. RDP África is a public service channel broadcasting from Lisbon to lusophone African countries.

12. Maria Ioannis Baganha, "Imigrantes em Portugal: uma Síntese Histórica," Ler História 56 (2009).

13. A total of 16 such programs started and ended between 2003 and 2009. The programs were discontinued because there was no perceived need for them (after initial support for newcomers and as other support structures to ease further settling in emerged) or because people left to seek better living conditions elsewhere due to the effects of the economic crisis.

14. Daniel Dayan, "Particularistic Media and diasporic communications," in Media, Ritual and Identity ed. Tamar Liebes and James Curran (New York: Routledge, 1998), 103113.

15. Benedict Anderson, Imagined Communities: Reflections on the Origin and Spread of Nationalism (London: Verso, 1983; rev. repr. 1991).

16. Blion, "Europe's Ethnic Media and Diversity Media", 68.

17. Homi Bhabha, "The Postcolonial and the Postmodern: The Question of Agency," in The Cultural Studies Reader, ed. Simon During (London: Routledge, 1999).

18. Bhabha's theory on the articulation of cultural difference was developed in discussions on post-colonialism, which is not always the context framing migrants' experiences in Portugal. Yet, the notion is useful because it emphasizes the position from which people articulate their cultural selves and the process of contingently translating and re-arranging cultural references.

19. Myria Georgiou, Mapping Diasporic Media across the EU: Addressing Cultural Exclusion. Political Science (London: EMTEL II, Media@LSE, London School of Economics and Political Science, 2003); Isabelle Rigoni, and Eugénie Saitta, "Democratizing the Public Space? Ethnic Minority Media in a Glocal Context," in Mediating Diversity in a Globalised Public Space, ed. Isabelle Rigoni and Eugénie Saitta (Basingstoke: Palgrave MacMillan, 2012); Roger Silverstone, and Myria Georgiou, "Editorial Introduction: Media and Minorities in Multicultural Europe," Journal of Ethnic and Migration Studies 31(3) (2005). 20. Susana Trovão, and Sónia Ramalho, Repertórios Femininos em Construção num Contexto Migratório Pós-Colonial: Dinâmicas Familiares, de Género e Geração, Vol. 1 (Lisbon: ACIDI, 2012).

21. Dynamics happening off air can be as (or more) significant than broadcasted narratives provided that local radio is but one forum of public visibility for these populations. For instance, Trovão and Ramalho (2012) identified initiatives such as Plataforma Gueto, a civic intervention project led by young African descendants, which actually recently started its own online station. In other words, dissatisfaction among migrant populations with under- and misrepresentation on mainstream media, as well as with generalized prejudice, does exist and has been documented by, respectively, Brites et al. (2009: 231-284) and Carvalheiro (2006: 73-93). Not (re)acting through the local radio programs may result from various factors (e.g. reluctance to antagonize the stations' hosting them, or divided opinions on integration matters which, as, Rigoni 
and Saitta (2012: 3) note, may trigger insurgent initiatives only in particular, situated instances).

22. Kira Kosnick, "Ethnic Media, Transnational Politics: Turkish Migrant Media in Germany," in Transnational Lives and The Media: Re-imagining Diaspora ed. Olga Guedes Bailey, M. Georgiou, and R. Harindranath (Basingstoke: Palgrave Macmillan, 2007), 165. 23. Ibid.

24. To be sure, Kosnick examines Turkish programs in German commercial, public and open (community-like) channels to question the idea that voices simply need forums to be heard. Although the discussion revolves around situations and processes operating very differently from those considered in this paper (e.g. the interference of governmental subsidies in the limits of assertion of "Otherness"), the author's reasoning is relevant to the extent that it underlines the complex relationship between cultural production, categorical identities and power.

25. Myria Georgiou, "Diasporic Media Across Europe: Multicultural Societies and the Universalism-Particularism Continuum," Journal of Ethnic and Migration Studies 31(3) (2005): 489.

26. Cited in Nabil Echchaibi, “(Be)longing Media: Minority Radio between Cultural Retention and Renewal," The Public 1 (2002): 39.

27. Mohammed ElHajji, "Rio de Janeiro - Montreal: Conexões Internacionais/Ruídos Interculturais," in Diásporas, migrações, tecnologias da comunicação e identidades transnacionais = Diásporas, migraciones, tecnologías de la comunicación e identidades transnacionales = Diaspora, migration, communication technologies and transnational identities, ed. Denise Cogo, Mohammed ElHaji and Amparo Huertas (Bellaterra/ Barcelona: Institut de la Comunicació, Universitat Autònoma de Barcelona, 2012).

28. Dhananjayan Sriskandarajah, and Catherine Drew, Brits Abroad: Mapping the Scale and Nature of British Emigration (London: Institute for Public Policy Research, 2006).

29. Kate Torkington, “Defining Lifestyle Migration," Dos Algarves 19 (2010).

30. Michaela Benson, and Karen O’Reilly, “Lifestyle Migration: Escaping to the Good Life?" In Lifestyle Migration: Expectations, Aspirations and Experiences, ed. Michaela Benson and Karen O'Reilly (Surrey and Burlington: Ashgate, 2009).

31. Nabil Echchaibi, “(Be)longing Media: Minority Radio between Cultural Retention and Renewal," The Public 1 (2002); Matthew Matsaganis, Vikki Katz, and Sandra BallRokeach, Understanding Ethnic Media: Producers, Consumers and Societies (Thousand Oaks: Sage, 2011): 15-16.

32. George Marcus, "Ethnography in/of the World System," Annual Review of Anthropology 24 (1995): 95-117.

33. Debra Spitulnik, “Anthropology and Mass Media," Annual Review of Anthropology 22(1) (1993): 293-315.

34. One such field revolved around efforts of social mobilization for various social causes (see David and Rosales, 2014).

35. European Broadcasting Union (EBU) - Strategic Information Service, Migration: An Overview (vol. 45) (Geneva: European Broadcasting Union, 2011).

36. The British Consul further estimated another 30,000 people who variably stay in the region as second-home owners and long-stay visitors.

37. Instituto Nacional de Estatística (INE), I. P. Censos 2011 Resultados Definitivos - Algarve (Lisbon: INE, 2012).

38. Kate Torkington, “Defining Lifestyle Migration,” Dos Algarves 19 (2010): 99-100. 
39. European Broadcasting Union (EBU) - Strategic Information Service, Migration: An Overview (vol. 45) (Geneva: European Broadcasting Union, 2011), 21.

40. Maria Ioannis Baganha, "Imigrantes em Portugal: uma Síntese Histórica," Ler História 56 (2009).

41. Isabel Ferin, Clara Almeida Santos, and Willy Filho, Media, Imigração e Minorias Étnicas 2005-2006 (Lisbon: ACIDI - Observatório da Imigração, 2008): 114.

42. Ibid.

43. EBU, Migration: An Overview, 19; Raquel Huete Nieves, Alejandro Mantecón Terán, and Tomás Mazón Martinez, “Analysing the Social Perception of Residential Tourism Development," in Proceedings of the IASK International Conference: Advances in Tourism Research, ed. Carlos Costa and Pedro Cravo (Aveiro: IASK, 2008): 158-160; Allan M. Williams, and C. Michael Hall, "Tourism, Migration, Circulation and Mobility: The Contingencies of Time and Place," in Tourism and Migration: New Relationships between Production and Consumption, ed. C. Michael Hall and Allan M. Williams (Dordrecht: Springer-Science+Business Media, B.V, 2002): 34-35.

44. Madeleine McCann was seven years old when she disappeared during her family holiday in Portugal, in May 2007. Inconclusive attempts to find her over the years have triggered much speculation, which Portuguese, British and international media have widely reported on.

45. Alexandra Noronha, “Governo lança programa 'reforma ao sol”, Jornal de Negócios, August 2, 2011, accessed March 15, 2014, http://www.jornaldenegocios.pt/economia/ detalhe/governo_lanccedila_programa_quotreforma_ao_solquot.html.

46. The program Reforma ao Sol (Retirement in the Sun) was designed in 2009 (as established in Decree-Law 249/2009, published in Diário da República, 1st series - Nr. 185 - 23 September 2009) but came into full effect only in 2013, in the specifications for the approval of the government budget (see Law nr. 66-B/2012, published in Diário da República, 1st series - Nr. 252 - 31 December 2012). Creating the exceptional category of "non-habitual residents" and exempting individuals from taxes over pensions received from another state is a strategy to make Portugal competitive among destinations with warm climates for retirees.

47. LUSA, "Vantagens fiscais tornam Portugal numa 'Florida da Europa'," SOL, September 15, 2013, accessed March 15, 2014, http://sol.sapo.pt/inicio/Economia/ Interior.aspx?content_id=85565.

48. Elsa Marujo, “Uma Família Inglesa," Linha da Frente (RTP, March 7, 2012), http:// www.rtp.pt/programa/tv/p28496/e5.

49. Vítor Rodrigues Oliveira, “Em Busca da Flórida Perdida," Antena Aberta (Antena 1, November 26, 2012), accessed March 15, 2014, http://cdn.rtp.pt/antena1/index.php? $\mathrm{t}=$ Em-busca-da-Florida-perdida-\%96-Reportagem-de-Vitor-RodriguesOliveira.rtp\&article $=5849$ \&visual $=11 \& \mathrm{tm}=12$ \&headline $=13$.

50. Ana Serafim, "Reformados Europeus Podem Render 2 Milhões de Euros a Portugal," SOL, August 3, 2011, accessed March 15, 2014, http://sol.sapo.pt/inicio/Sociedade/ Interior.aspx?content_id=25597.

51. As the author notes, these images accompanied the growth of mass tourism and second-home ownership among the British who settled, namely, in Spain.

Documentaries, TV dramas, comedy sitcoms and news reports were frequent in the 1990s and have since become scanter provided the lack of novel sensationalist aspects to explore. See Karen O'Reilly, “'Blackpool in the Sun': Images of the British on the 
Costa del Sol," in Media and Migration: Constructions of Mobility and Difference, ed. R. King and N. Wood (London and New York: Routledge, 2001).

52. King et al., Sunset Lives, 127-156; Torkington, “Defining Lifestyle Migration”, 99-100.

53. King et al., Sunset Lives, 137.

54. Myria Georgiou, "Diasporic Media Across Europe", 491-492; Kosnick, "Ethnic Media, Transnational Politics: Turkish Migrant Media in Germany”, 150-151; Stephen Harold Riggins, "The Media Imperative: Ethnic Minority Survival in the Age of

Communication", in Ethnic Minority Media. An International Perspective, ed. Stephen Riggins (Los Angeles: Sage, 1992): 276.

55. Steven Vertovec, "Fostering Cosmopolitanisms: A Conceptual Survey and a Media Experiment in Berlin," ESRC Transnational Communities Research Program, Working Paper Series, WPTC-2K-06, 2000, accessed May 6, 2014, http://www.transcomm.ox.ac.uk/ working\%20papers/vertovec.pdf, p. 276.

56. Torkington, "Defining Lifestyle Migration", 100; Williams and Hall, "Tourism, Migration, Circulation and Mobility", 6-8; King et al., Sunset Lives, 34-37.

57. Boaventura Sousa Santos, "Estado e sociedade na semiperiferia do sistema mundial: o caso português," Análise Social XXI (87-89) (1985).

58. While it is important to highlight what is a structuring relation, the point is not to sustain trickle-down ideas apparent in globalization theories. A number of authors have highlighted alternative circuits, hegemonic references and situated points of view, as the titles of their works often suggest (e.g. "Travelling Sounds: Whose center, Whose periphery?" (Chambers: 1993) or "Indian Films and Nigerian Lovers: Media and the Creation of Parallel Modernities" (Larkin: 1997)). Yet, this case sheds light on a singular aspect of the most commonly discussed configuration interrelating centers and peripheries: the presence of dominant references not because of appropriation by locals (who access them through mediascapes), but because of the cultural reproduction practices among dislocated people coming from a center.

59. Williams and Hall, "Tourism, Migration, Circulation and Mobility".

60. Myria Georgiou, Mapping Diasporic Media across the EU, 63; Salim, Os meios de comunicação étnicos em portugal, 53-56.

61. Arjun Appadurai, Modernity at Large: Cultural Dimensions of Globalization (Minneapolis: University of Minneapolis Press, 1996).

62. Katz Matsaganis and Ball-Rokeach, Understanding Ethnic Media, 139; Silverstone and Georgiou, "Editorial Introduction: Media and Minorities in Multicultural Europe".

63. Law nr. 54/2010, published in Diário da República, 1st series - Nr. 248, December 24, 2010.

64. Karim H. Karim, "From Ethnic Media to Global Media: Transnational Communication Networks Among Diasporic Communities," ESRC Transnational Communities Research Program, Working Paper Series, WPTC-99-02, 1999, accessed May 6, 2014, http://www.transcomm.ox.ac.uk/working\%20papers/karim.pdf, p. 8.

65. See, for instance, Filomena Silvano, Marta Rosales, and Sónia Ferreira, "Gente da Nossa: Uma construção mediática da ideia de 'comunidade Portuguesa'," Portuguese Studies Review 20(2) (2012).

66. Michal Bilig, Banal Nationalism (London/Thousand Oaks/New Delhi: Sage Publications, 1995).

67. Fieldnotes, November 13, 2011.

68. Paddy Scannell, "For-Anyone-as-Someone Structures," Media, Culture and Society 22 (2000): 19. 
69. Bilig, Banal Nationalism.

70. Scannell, "For-Anyone-as-Someone Structures".

71. Benson and O’Reilly, “Lifestyle Migration: Escaping to the Good Life?", 9-11.

\section{ABSTRACTS}

This paper explores an under-researched case in the media and minorities field: initiatives concerning relatively privileged populations. After outlining the findings of a selfproduced mapping of minority radio initiatives in Portugal, the paper explores the role of a local station founded by, and largely catering to, self-designated "expatriates" residing in the country's touristic southern region of the Algarve. In dialogue with literature on minority media, it problematizes the issues of inclusion and exclusion, voice, transnational connectivity and cultural reproduction that are central to mediated self-representation in migratory contexts. It argues that media pertaining to relatively privileged populations should be included in the field of minority media.

Drawing on an ethnographic approach it further discusses the specificities of a station catering to a population for whom integration is not always a goal provided international relocation is driven by the search of amenities and "a better quality of life". By exploring how Bright FM contributes to expressing and (re)constructing the cultural identity of the (mostly British) "expatriate" population, the paper suggests the usefulness of considering lifestyle migrants' media as a particular category to conceptualize initiatives produced by and for people whose mobilities are best understood through the framework of lifestyle migration.

\section{INDEX}

Keywords: radio, minority media, lifestyle migration, British, Algarve

\section{AUTHOR}

\section{INÊS DAVID}

Inês David is a Ph.D. candidate in anthropology at the Faculty of Social Sciences and Humanities of NOVA University in Lisbon, Portugal. She is a member of the Center for Research in Anthropology (CRIA) and a research assistant at the University of Lisbon, Institute of Social Sciences. Her doctoral project takes a media anthropology approach to mediated selfrepresentation in migratory contexts and, specifically, to radio founded by and largely catering to self-designated "expatriates". She has also been involved in research projects on international mobilities focusing on female-led migration and material culture. 